\title{
THE RISK FACTOR FOR MORTALITY IN COVID-19 PATIENTS IN MOHAMMAD HOESIN HOSPITAL, PALEMBANG, INDONESIA
}

\author{
Rico Januar Sitorus, ${ }^{1 *}$ Nyoman Yudi Antara, ${ }^{2}$ Rosyada Elviani, ${ }^{3}$ Zen Ahmad, ${ }^{3}$ Harun Hudari, ${ }^{3}$ \\ Reymart V. Sangalang ${ }^{4}$ \\ ${ }^{1}$ Faculty of Public Health Sriwijaya University, Jl. Palembang-Prabumulih KM 32 Ogan Ilir, 30662, Indonesia \\ ${ }^{2}$ Faculty of Public Health Kader Bangsa University, Jl. Mayjend H.M Ryacudu, No. 88 \& ulu Plembang, \\ 30253 , Indonesia \\ ${ }^{3}$ Mohammad Hoesin Hospital, Jl. Jend. Sudirman KM. 3,5, Sekip Jaya, Kemuning, Palembang City, 30126 \\ Indonesia \\ ${ }^{4}$ De La Salle University, Manila. 0922 Philippines
}

\begin{abstract}
World Health Organization (WHO) has declared the novel corona virus (COVID-19) as a pandemic due to its high transmission and the rapid spread of the COVID-19. Along these lines, there is a need for more research about risk factors that can affect the spread of COVID-19 and its fatality. Therefore, this study aims to analyze risk factors in patients who died from COVID-19 at the Mohammad Hoesin Hospital in Palembang, South Sumatra, Indonesia. This study used a cross-sectional approach. The data were collected from all patients who died with suspected, probable, and confirmed status until September 2020 Data on death due to COVID-19 were collected with suspect, probable, and confirmed status. The results showed that comorbidity became the most dominant factor (62.1\%) with (OR Adj) 3.780 (1.000 - 3.168) after controlling for contact history with confirmed cases and sex. There were differences in the mean age and length of stay in patients with confirmed COVID-19 and not. Prevention of death in COVID-19 patients can be done by controlling comorbidities and contact history with positive cases of COVID-19.
\end{abstract}

Keywords: age, comorbid, contact history, COVID -19, mortality, sex.

\begin{abstract}
ABSTRAK
Organisasi Kesehatan Dunia (WHO) telah menyatakan virus korona baru (COVID-19) sebagai pandemi karena tingkat penularannya yang tinggi dan penyebaran COVID -19 yang cepat. Sejalan dengan hal tersebut, diperlukan penelitian lebih lanjut tentang faktor risiko yang dapat mempengaruhi penyebaran COVID -19 dan kematiannya. Oleh karena itu, penelitian ini bertujuan untuk menganalisis faktor risiko pada pasien yang meninggal akibat COVID -19 di Rumah Sakit Mohammad Hoesin Palembang, Sumatera Selatan, Indonesia. Penelitian ini menggunakan pendekatan cross-sectional. Data dikumpulkan dari seluruh pasien yang meninggal dengan status suspek, probable, dan konfirmasi sampai September 2020. Data kematian akibat COVID -19 dikumpulkan dengan status suspek, probable, dan terkonfirmasi. Hasil penelitian menunjukkan bahwa komorbiditas menjadi faktor yang paling dominan (62,1\%) dengan (OR Adj) 3,780 (1.000 - 3.168) setelah dikontrol dengan riwayat kontak dengan kasus terkonfirmasi dan jenis kelamin. Terdapat perbedaan rerata umur dan lama rawat pasien dengan pasien konfirmasi COVID-19 dan pasien tidak konfirmasi COVID-19. Pencegahan kematian pada pasien COVID -19 dapat dilakukan dengan mengontrol penyakit penyerta dan riwayat kontak dengan kasus positif COVID -19 .
\end{abstract}

Kata Kunci: usia, komorbid, riwayat kontak, COVID -19, mortalitas, jenis kelamin. 


\section{Introduction}

The first novel corona virus (COVID-19) case was found in China and reported in December 2019. It has spread rapidly to over 210 countries worldwide. COVID-19 has high morbidity and mortality rates globally and becomes pandemic according to, World Health Organization (WHO). ${ }^{1}$ The COVID-19 caused respiratory tract infection followed by several symptoms such as common cold, fever, dry cough, shortness of breath, up to more severe symptoms. ${ }^{2,3}$

The pandemic poses many challenges in providing health care. Elderly groups and people with health problems such as hypertension, heart problems, and diabetes are susceptible being infected with this virus. It can deteriorate a person's condition and even increase the risk of death. The potential for transmission of this disease can also be from people that are asymptomatic., ${ }^{4,5}$

Transmission of this disease can occur in hospitals. The most recent case reported $41 \%$ of infected patients were in the hospital, $29 \%$ were medical staff with a death rate of $4.3 \%{ }^{6}$ The risk factors for death related to COVID-19 are elderly with ages 65 years and over that accompanied by comorbidities. Michelozzi (2020) showed men have a higher risk of death than women. ${ }^{7}$ The United States reports that $71 \%$ (732/1037) of COVID-19 sufferers are hospitalized. ${ }^{8}$ M.Hoesin hospital is one of the hospitals that care for patients with a positive confirmation COVID 19. The number of positive cases that hospitalized Moh. Hoesin is 334 people with the number of deaths 47 people. ${ }^{9}$

In reducing transmission, it is necessary to restrict local and international travel and implement quarantine. Travel restrictions can mitigate potential transmission from local transmission areas. ${ }^{10}$ Movement of the population such as going to the office by public transportation and traveling to the infected areas can increase risk transmission when returning home. ${ }^{11}$ The death toll due to COVID -19 in the world is $2.85 \%$. ${ }^{1}$ Properly treated COVID-19 patients can reduce morbidity and mortality in this pandemic. Medical workers must be equipped with adequate knowledge, skills on preventive measures, and confidence in diagnosing and treating COVID-19 patients. Medical workers who are directly involved in the diagnosis, treatment and care of COVID-19 patients have a high-risk exposure to the virus from aerosol and droplet contamination. This caused nosocomial infections. ${ }^{12}$

As part of the ongoing pandemic preparedness, this research aim is to analyze risk factors of death in the hospital and to help service health management design protocol in determiner proper handling of COVID-19 patients.

\section{Method}

This study used a cross-sectional approach using medical records and COVID-19 surveillance data in September 2020 from Mohammad Hoesin Hospital. The data were collected from all patients who died with suspected, probable, and confirmed status until September 2020. Mohammad Hoesin 
Hospital is a national referral hospital and accepts COVID-19 patients from all districts in South Sumatra.

The study's independent variables were sex, age, length of stay, contact history with positive confirmed cases, comorbidities, and chief complaint in admission to hospital. The dependent variable was patient death status (suspected, probable, and confirmed), based on the respondent's medical record.

The data analyzed were from the 235 patients who went to the hospital and died till September 2020 amid this pandemic. Data analysis was performed by univariate, bivariate, and multivariate. The univariate analysis provides an overview of the variables studied, bivariate analysis examines the relationship between the independent variables and the dependent variable using the chi-square test, and multivariate analysis explain the character of the predictor variables in explaining the dependent variable with multiple logistic regression. This study has been reviewed and received ethical clearance from the Mohammad Hoesin Hospital with No. 10 / kepkrsmh / 2020.

\section{Results}

Table 1 shows data on COVID-19 patient death status. 40.9\% was confirmed, 55.7\% was probable status, $3.4 \%$ was suspected, $62.1 \%$ with comorbidities and $71.5 \%$ did not know that they had contact with positive cases. At the time of admission to the hospital, the most chief complaint was dyspnea (30.3\%). 
Table 1. Characteristic of respondent COVID-19 patient $(n=235)$

\begin{tabular}{llcc}
\hline \multicolumn{1}{c}{ Variables } & \multicolumn{1}{c}{ Categories } & $\mathbf{n}$ & $\mathbf{\%}$ \\
\hline Patient death status & Confirmed & 96 & 40.9 \\
& Probable & 131 & 55.7 \\
Contact history & Suspected & 8 & 3.4 \\
& Yes & 43 & 18.3 \\
& Not known & 168 & 71.5 \\
Comorbidity & Yo & 24 & 10.2 \\
& Yes & 146 & 62.1 \\
Chief complaint of admission & Dyspnea & 89 & 37.9 \\
& Dyspnea and loss of consciousness & 71 & 30.3 \\
& Loss of consciousness & 36 & 15.3 \\
& Cough & 14 & 6 \\
& Dyspnea and fever & 10 & 4.3 \\
& Limp & 24 & 10.2 \\
& Nausea and vomiting & 6 & 2.6 \\
& Unstable bradycardia & 2 & 0.9 \\
& Trauma dan RO Pneumonia & 1 & 0.4 \\
& Fever & 6 & 2.6 \\
& Cough and dyspnea & 3 & 1.3 \\
& Dyspnea and limp & 10 & 4.3 \\
Age (years) & Abdominal pain & 12 & 5.1 \\
& Planning for blood transfusion & 1 & 0.4 \\
& Planning for chemotherapy & 1 & 0.4 \\
& Respiratory failure & 1 & 0.4 \\
& None & 2 & 0.9 \\
& Mean - Median & 35 & 14.9 \\
\hline
\end{tabular}

Table 2 shows that among the 3 variables (gender, comorbidity, and contact history with confirmation), the contact history with positive cases had a significant relationship with the dead COVID-19 patients with sig $(0.017<\alpha=0.05)$. This suggests that contact history with positive COVID-19 confirmed patients was associated with mortality status. Variables with sig $<0.25$ were candidates for multivariate analysis with multiple logistic regression. Table 2 shows that the variables for sex, comorbidity, and confirmed contact history were included in the multivariate analysis.

Table 2. Bivariable analysis of factors associated with COVID-19

\begin{tabular}{|c|c|c|c|c|c|c|}
\hline \multirow{3}{*}{ Variable } & \multirow{3}{*}{ Category } & \multicolumn{4}{|c|}{ COVID-19 Cases } & \multirow{3}{*}{ p-value } \\
\hline & & \multicolumn{2}{|c|}{ Confirmed } & \multicolumn{2}{|c|}{$\begin{array}{l}\text { Not yet confirmed } \\
\text { (probable + suspect) }\end{array}$} & \\
\hline & & n & $\%$ & $\mathbf{n}$ & $\%$ & \\
\hline \multirow[t]{2}{*}{ Sex } & Male & 65 & 46.1 & 76 & 53.9 & \multirow{2}{*}{0.062} \\
\hline & Female & 31 & 33 & 63 & 67 & \\
\hline \multirow[t]{2}{*}{ Comorbidity } & Yes & 67 & 45.9 & 79 & 54.1 & \multirow{2}{*}{0.061} \\
\hline & No & 29 & 32.6 & 60 & 67.4 & \\
\hline \multirow{3}{*}{$\begin{array}{l}\text { History of contact with } \\
\text { confirmed case }\end{array}$} & Yes & 15 & 34.9 & 28 & 65.1 & 0.0000 \\
\hline & Not known & 77 & 45.8 & 91 & 54.2 & \multirow{2}{*}{0,017} \\
\hline & No & 4 & 16.7 & 20 & 83.3 & \\
\hline
\end{tabular}

In Table 3, the most dominant variable in predicting mortality in COVID-19 patients was comorbidity with an Odds Ratio (OR Adj) value of 3,780 $(1,000$ - 3,168) after controlling for contact 
history with confirmed cases and sex. This result showed that COVID-19 patients with comorbidities had a 3,780 times greater risk of dying than patients who do not have comorbidities.

Confirmed positive COVID-19 patients who did know had a history of contact with confirmed cases had a greater risk of death $2,055(0.572-7,381)$ times compared to patients who had no contact history with confirmed cases, then confirmed positive COVID-19 patients who had a history of contact with confirmed cases had a greater risk of death 3,666 (1,176 - 11,429) times compared to patients who had no contact history with confirmed cases after controlling with comorbidity and sex.

Table 3. Multivariate analysis with Multiple Logistic Regression

\begin{tabular}{llccc}
\hline \multicolumn{1}{c}{ Risk Factors } & Category & B & p-value & OR (95\% CI) \\
\hline Comorbidity & No & & & Reff \\
& Yes & 0.577 & 0.050 & $3.780(1.000-3.168)$ \\
History of contact with confirmed & No & & & Reff \\
case & Not known & 0,720 & 0.270 & $2.055(0.572-7.381)$ \\
& Yes & 1.2991 & 0.025 & $3.666(1.176-11.429)$ \\
\hline
\end{tabular}

\section{Discussion}

The presence of comorbid, age, and ethnicity are factors that affects the survival and mortality rates for people with COVID-19. ${ }^{13,14}$ This study reported that COVID-19 patients who died with comorbidity $(61.2 \%)$ were more than patients those without. Comorbidity such as hypertension, diabetes, and heart disease known to increase mortality. ${ }^{14}$ Cardiac Comorbidity, Acute Heart Injury Chronic Kidney Disease, Acute Kidney Injury are Associated with Increased Disease Severity in Patients with COVID-19, ${ }^{15}$ age significantly affected $(p=0.0007)$ when compared between positive confirmed patients and those who were not. The sex variable in this study was dominated by men. Men over 65 years are known to have a higher mortality rate than women in people with COVID-19. ${ }^{16,17}$ This can be due to differences in innate immune system responses such as cytokines and chemokines. Men have a higher innate immune response than women and this can aggravate the condition of people with COVID-19. Moreover, activated T cells increased significantly in female patients but not in Men. ${ }^{18}$ Symptoms frequently appear in patients of COVID-19 are fever, cough, shortness of breath, muscle pain, headache, sore throat, rhinorrhea, diarrhea, and vomiting. ${ }^{19}$ In severe conditions, patients in intensive care unit had difficulty breathing compared to patients who were not, ${ }^{20}$ Allegedly, chief complaint upon admission to the hospital in this study were related to the mortality rate characterized by difficulty breathing or dyspnea. In this study, dyspnea was the most common chief complaint (30.3\%) in admission to hospital among people with COVID-19. Another risk factor related to the mortality rate in this study was close contact with a confirmed COVID-19 patient. The high incidence of COVID-19 patients is related to close contact between currently and previously positive patients. The spread of SARS-COV-2 through close contact can occur through 
people who are symptomatic or asymptomatic, making the spread unnoticeable. SARS-COV-2 screening on people with close contact with sufferers of COVID -19 can reduce the spread of this disease. $^{21}$

\section{Conclusion}

This study showed that COVID-19 patients who died at the hospital suffered from dyspnea as symptom and had contact history with positive confirmed COVID-19 patients. Patients who had comorbidities had a greater risk of suffering fatality than patients who do not have comorbidities.

\section{Acknowledgment}

We would like to thank to Mohammad Hoesin hospital for supporting this study

\section{Funding}

There is no funding for this research, and the funds used are the author's personal funds.

\section{Conflict of Interest}

The authors declare that there is no conflict of interest

\section{References}

1. Https://covid19.who.int. WHO Coronavirus Disease (COVID-19) Dashboard Data last updated: 2020/10/14, 4:14pm CESThttps://covid19.who.inte.

2. van der Hoek L, Pyrc K, Jebbink MF, Vermeulen-Oost W, Berkhout RJM, Wolthers KC, Wertheim-van Dillen PME, Kaandorp J, Spaargaren J, Berkhout B. Identification of a new human coronavirus. Nat Med [Internet]. 2004;10(4):368-73. Tersedia pada: https://doi.org/10.1038/nm1024

3. Huang C, Wang Y, Li X, Ren L, Zhao J, Hu Y, Zhang L, Fan G, Xu J, Gu X. Clinical features of patients infected with 2019 novel coronavirus in Wuhan, China. Lancet. 2020;395(10223):497-506.

4. WHO. WHO Corona Virus Disease (COVID19). WHO. 2020.

5. Rothe C, Schunk M, Sothmann P, Bretzel G, Froeschl G, Wallrauch C, Zimmer T, Thiel V, Janke C, Guggemos W, Seilmaier M, Drosten C, Vollmar P, Zwirglmaier K, Zange S, Wölfel R, Hoelscher M. Transmission of 2019-NCOV infection from an asymptomatic contact in Germany. N Engl J Med. 2020;382(10):970-1.

6. Wang D, Hu B, Hu C, Zhu F, Liu X, Zhang J, Wang B, Xiang H, Cheng Z, Xiong Y, Zhao Y, Li Y, Wang X, Peng Z. Clinical Characteristics of 138 Hospitalized Patients With 2019 Novel 
Coronavirus-Infected Pneumonia in Wuhan, China. JAMA [Internet]. 17 Maret 2020;323(11):1061-9. Tersedia pada: https://doi.org/10.1001/jama.2020.1585

7. Michelozzi P, de'Donato F, Scortichini M, Pezzotti P, Stafoggia M, De Sario M, Costa G, Noccioli F, Riccardo F, Bella A, Demaria M, Rossi P, Brusaferro S, Rezza G, Davoli M. Publisher Correction to: Temporal dynamics in total excess mortality and COVID-19 deaths in Italian cities. BMC Public Health [Internet]. 2020;20(1):1325. Tersedia pada: https://doi.org/10.1186/s12889-020-09398-7

8. Covid CDC, COVID CDC, COVID CDC, Chow N, Fleming-Dutra K, Gierke R, Hall A, Hughes M, Pilishvili T, Ritchey M. Preliminary estimates of the prevalence of selected underlying health conditions among patients with coronavirus disease 2019-United States, February 12-March 28, 2020. Morb Mortal Wkly Rep. 2020;69(13):382.

9. https://dinkes.sumselprov.go.id/2020/08/update-situasi-covid-19-sumsel-15-agustus-2020/.

10. Papadimos TJ, Marcolini EG, Hadian M, Hardart GE, Ward N, Levy MM, Stawicki SP, Davidson JE. Ethics of Outbreaks Position Statement. Part 2: Family-Centered Care. Crit Care Med [Internet]. 2018;46(11):1856-60

11. Zhang C, Chen C, Shen W, Tang F, Lei H, Xie Y, Cao Z, Tang K, Bai J, Xiao L. Impact of population movement on the spread of $2019-\mathrm{nCoV}$ in China. Emerg Microbes Infect. 2020;9(1):988-90.

12. Organization WH. Modes of transmission of virus causing COVID-19: implications for IPC precaution recommendations: scientific brief, 29 March 2020 [Internet]. Geneva PP Geneva: World Health Organization; Tersedia pada:

https://apps.who.int/iris/handle/10665/331616

13. Li AY, Hannah TC, Durbin JR, Dreher N, McAuley FM, Marayati NF, Spiera Z, Ali M, Gometz A, Kostman J, Choudhri TF. Multivariate Analysis of Factors Affecting COVID-19 Case and Death Rate in U.S. Counties: The Significant Effects of Black Race and Temperature. 2020;30:321.

14. Zhou F, Yu T, Du R, Fan G, Liu Y, Liu Z, Xiang J, Wang Y, Song B, Gu X, Guan L, Wei Y, Li $\mathrm{H}, \mathrm{Wu} \mathrm{X}, \mathrm{Xu}$ J, Tu S, Zhang Y, Chen H, Cao B. Clinical course and risk factors for mortality of adult inpatients with COVID-19 in Wuhan, China: a retrospective cohort study. Lancet. 2020;395(10229):1054-62.

15. Wang X, Fang X, Cai Z, Wu X, Gao X, Min J, Wang F. Comorbid Chronic Diseases and Acute Organ Injuries Are Strongly Correlated with Disease Severity and Mortality among COVID-19 Patients: A Systemic Review and Meta-Analysis. Research [Internet]. 2020;2020:2402961. Tersedia pada: https://doi.org/10.34133/2020/2402961

16. Driscoll M, Ribeiro Dos Santos G, Wang L, Cummings DAT, Azman AS, Paireau J, Fontanet A, Cauchemez S, Salje H. Age-specific mortality and immunity patterns of SARS-CoV-2 
infection in 45 countries. medRxiv. Januari 2020;2020.08.24.20180851.

17. Pastor-Barriuso R, Perez-Gomez B, Hernan MA, Perez-Olmeda M, Yotti R, Oteo J, Sanmartin JL, Leon-Gomez I, Fernandez-Garcia A, Fernandez-Navarro P, Cruz I, Martin M, Delgado-Sanz C, Fernandez de Larrea N, Paniagua JL, Munoz-Montalvo JF, Blanco F, Larrauri A, Pollan M, Pollan M. Infection fatality risk for SARS-CoV-2: a nationwide seroepidemiological study in the non-institutionalized population of Spain. medRxiv. Januari 2020;2020.08.06.20169722.

18. Takahashi T, Ellingson MK, Wong P, Israelow B, Lucas C, Klein J, et al. Sex differences in immune responses that underlie COVID-19 disease outcomes. Nature. 2020;588:315-20

19. Chen N, Zhou M, Dong X, Qu J, Gong F, Han Y, Qiu Y, Wang J, Liu Y, Wei Y. Epidemiological and clinical characteristics of 99 cases of 2019 novel coronavirus pneumonia in Wuhan, China: a descriptive study. Lancet. 2020;395(10223):507-13.

20. Wang D, Hu B, Hu C, Zhu F, Liu X, Zhang J, Wang B, Xiang H, Cheng Z, Xiong Y, Zhao Y, Li Y, Wang X, Peng Z. Clinical Characteristics of 138 Hospitalized Patients With 2019 Novel Coronavirus-Infected Pneumonia in Wuhan, China. JAMA. Maret 2020;323(11):1061-9.

21. Martinez-Fierro ML, Ríos-Jasso J, Garza-Veloz I, Reyes-Veyna L, Cerda-Luna RM, Duque-Jara I, Galvan-Jimenez M, Ramirez-Hernandez LA, Morales-Esquivel A, Ortiz-Castro Y, Gutierrez-Camacho JR, Valdes-Aguayo JJ, Vargas-Rodriguez JR. The role of close contacts of COVID-19 patients in the SARS-CoV-2 transmission: an emphasis on the percentage of non-evaluated positivity in Mexico. Am J Infect Control [Internet]. 2020; Tersedia pada: http://www.sciencedirect.com/science/article/pii/S0196655320308981 